\title{
下新川海岸におけるうねり性巨大波浪の変形機構

\author{
Deformation of Long-period Giant Waves on the Shimoniikawa Coast
}

\author{
深瀬祐太朗 $^{1} \cdot$ Suminda Ranasinghe ${ }^{2}$. 田島芳満 ${ }^{3} \cdot$ 佐藤愼司 ${ }^{4}$ \\ Yutaro FUKASE, Suminda RANASINGHE, Yoshimitsu TAJIMA and Shinji SATO
}

\begin{abstract}
Deformation of long-period giant waves, which caused serious coastal damages in Toyama and Sado Island on February 24, 2008, was investigated on the basis of field data analyses and numerical modelling. Field data obtained at the depth of $12.8 \mathrm{~m}$ indicated significant nonlinear development of wave energy spectrum, both in the low frequency and in the double frequency ranges. Strong longshore currents were rapidly developed at the same time with the attack of giant waves. Wave energy concentration to the damaged area was found to be resulted by interactions among waves, bathymetry and nearshore currents.
\end{abstract}

\section{1.はじめに}

2008 年 2 月に発生した日本海高波災害では，寄り回り 波とも呼ばれるうねり性巨大波浪により富山湾や佐渡島 などで甚大な被害が生じた. 波浪の発達機構については, 各種波浪推算モデルなどで詳細な検討が進んでいるが, 沿岸部での波浪変形や局所集中機構については，複雑な 海底地形によるエネルギーの収斂や急勾配地形による波 力増大などが指摘されているものの, 未解明な部分が多 い. 本研究では, 水深約 $13 \mathrm{~m}$ の地点で取得された貴重な 現地デー夕を分析することで波浪と流れの特性を詳細に 把握するとともに数值モデルによる推算を実施し, 沿岸 域におけるうねり性波浪の挙動を解明することを目的と した。

データの分析及び数值モデルによる計算を行った対象 地域は、富山湾沿岸東部に位置する下新川海岸である (図-1).2008年2月24日の高波災害の際の詳細なデー夕 は黒部川東部の田中観測所において得られており，それ によると有義波高 $6.62 \mathrm{~m}$, 有義波周期 $13.9 \mathrm{~s}$ が観測され， いずれも下新川海岸の計画波高, 周期を上回るものであ った. 本研究では田中観測所で得られた波浪に関するデ ータをスペクトル波形や沿岸流を含めて詳細に分析し, 同地点において沿岸部海底地形データをもとに数值モデ ルを用い, 波高・沿岸流分布についての推算を行った. 推算については物的, 人的被害の大きかった芦崎地区及 び生地地区周辺についても同様に行った.

$\begin{array}{llll}1 & \text { 学生会員 } & \text { 学(工) } & \begin{array}{l}\text { 東京大学大学院工学系研究科 } \\ \text { 社会基盤学専攻 }\end{array} \\ 2 & \text { 非会 } & \text { 修(工) } & \text { 同上 } \\ 3 & \text { 正会貝 } & \text { Ph.D. } & \text { 東京大学准教授 同上 } \\ 4 & \text { フェロー } & \text { 工博 } & \text { 東京大学教授 同上 }\end{array}$

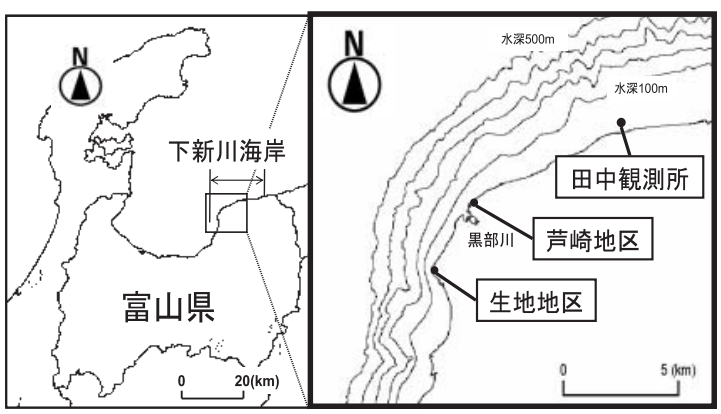

図-1 データ分析及び数值計算対象地点

\section{2. 田中観測所データを用いたうねり性波浪のス ペクトル分析}

田中観測所で得られたデー夕は，水深 $12.8 \mathrm{~m}$ の海底に 設置された海象計で取得された水位, 水圧, 中層（底面 上 $5.8 \mathrm{~m}$ ) ・底層（底面上 $2.8 \mathrm{~m}$ ）における流速および流向, 陸地で観測された風向・風速である。本研究では2008年 2 月 14 日 0 時 10 分から 2008 年 2 月 29 日 23 時 50 分まで 0.5 秒ごとに記録されたものを分析した．取得されたデータ のうち，水位は超音波水位計によるものであるが，この 情報は波浪ピーク期間において気泡混入の影響によりデ ータが欠損していたため, 水圧データを水位に換算した ものを用いた。 その際, 浅水域での微小振幅波理論を用 いることとし, $\eta_{p}$ を海水密度を $1.03 \mathrm{~g} / \mathrm{cm}^{3}$ とした圧力水頭, $k, h$ をそれぞれ波数, 水深 $(12.77 \mathrm{~m})$ として水位 $\eta$ を式 (1)によって定めた.

$$
\eta=\eta_{p} \cosh k h
$$

式（1）によって得られた水位を用いて 2 月 14 日 0 時 10 分から 2 月 29 日 23 時 50 分まで 20 分ごとにフーリエ変換 を用いてスペクトル解析を行った。式（1）によるスペ クトル強度值の過大評価を避けるため, $\cosh k h \leqq 3.0$ を 満たす領域，すなわち $\log _{10}(f) \leqq-0.75(f \leqq 0.18 \mathrm{~Hz})$ なる 


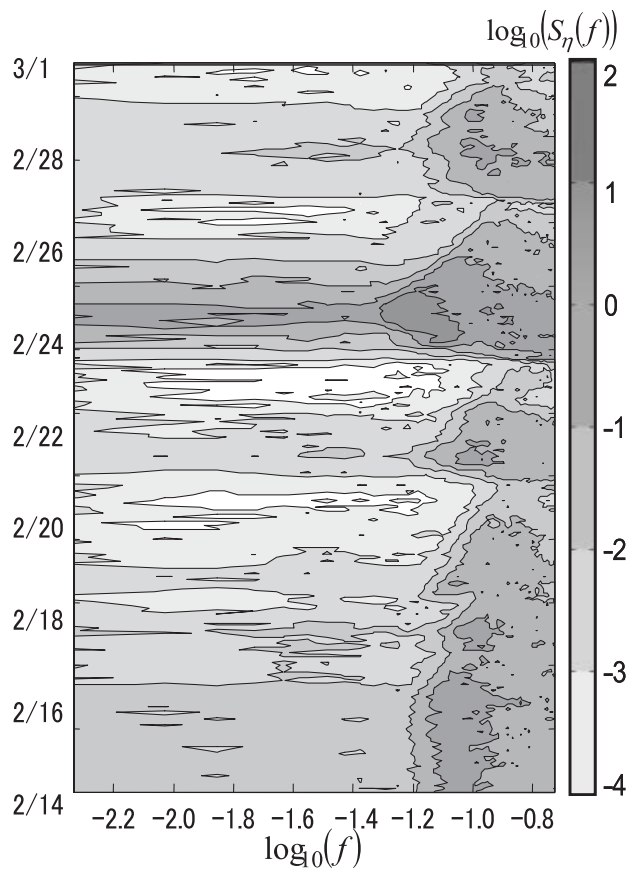

図-2 田中観測所におけるスペクトル密度の時系列変動

領域においてスペクトル密度の常用対数の時系列変化を 等高線図として表したものが図-2である。これを見ると， うねり性巨大波浪が来襲した2月24日から2月25日まで にかけて特にスペクトルのピーク強度が大きくなってい ることが分かる.また，この期間では周期 $T=30 \mathrm{~s}$ 以上 （図-2に扔いて $\log _{10}(f)=-1.5$ 以下）の長周期変動成分やピ 一ク周波数の 2 倍の周波数帯に打ける倍周波数成分のス ペクトル密度も発達していることが確認された。

次に, 周期 $T=25 \mathrm{~s}$ 以上 (図-2 に抏いて $\log _{10}(f)=-1.40$ 以下) の波浪成分を長周期変動成分 $\eta_{l}$, それ以外を短周期変動 成分 $\eta_{s}$ とし, それぞれについて成分波振幅の周波数带に 対する $\mathrm{rms}$ 值 $\sqrt{\eta_{l}^{2}}, \sqrt{\eta_{s}^{2}}$ を計算し, 時系列変化を図化して 図-3を得た。図から，うねり性波浪来襲時の2月24日は 他の時刻に比べて長周期, 短周期ともに $\mathrm{rms}$ 值が大きく, さらに短周期変動成分に対する長周期変動成分の割合が 高くなっていることが確認された。したがって，うねり 性巨大波浪来襲時は他の時刻に比べ, 長周期変動成分が 支配的であったということが推察される.

さらに, 長周期成分, 短周期成分の $\mathrm{rms}$ 值の関係を対 数軸上でプロットし, 波浪来襲時の 2 月 24 日のデー夕を 区別して表示して図-4を得た。この図からも2月24日に おいては長周期, 短周期共に成分波振幅の rms 值が大き くなっていることが確認された。また， $\sqrt{\eta_{s}^{2}} \geqq 0.1 \mathrm{~m}$ とな る領域に扔いて対数軸上で長周期変動成分 $\mathrm{rms}$ 值と短周 期変動成分の $\mathrm{rms}$ 值は傾き 2 の直線と平行に分布してお り, 両者は互いに2次, すなわち非線形の関係となって

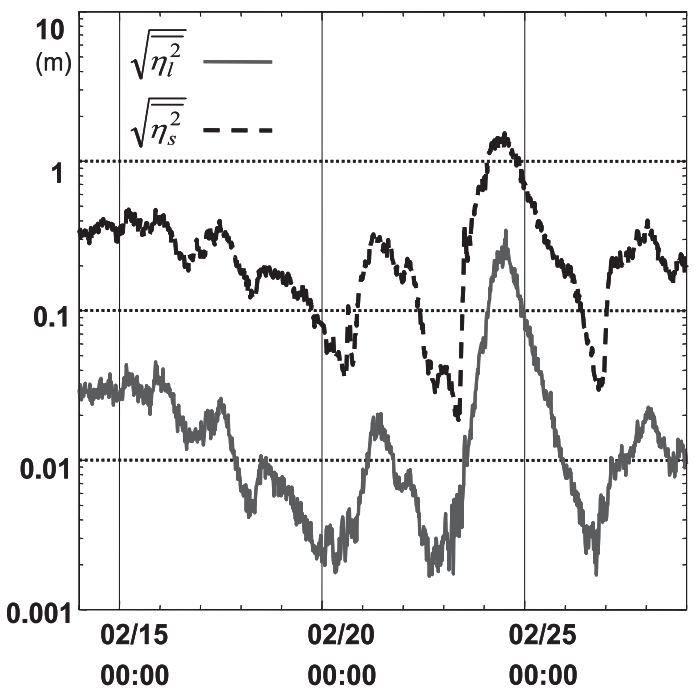

図-3 長周期帯及び短周期帯の rms 值の時系列変動

いることが分かった.

このことから, 波浪の長周期変動成分は非線形干渉に よって生じているということが推察される.これを検証 するため, 浜田（1964）の二次干涉理論を用いて巨大波 浪来襲時の非線形干渉波を計算した。 まず，ある時刻を 含んだ 20 分間のスペクトル強度分布からピーク周波数 $f_{p}$ を中心とした $0.04 \mathrm{~Hz}$ 周波数帯に含まれる成分波を線形成 分波とみなして, 浜田（1964）の理論により長周期変動 成分波, 倍周波数変動成分波を算出した. 線形波, 非線 形波の全てを合計した水位変動データを得, 再度スペク トル解析を行った. その結果を示したものが図-5である.

図-5と図-2を比較すると倍周波数成分はかなり過大評 価されてはいるが, 長周期である低周波数帯では特に巨

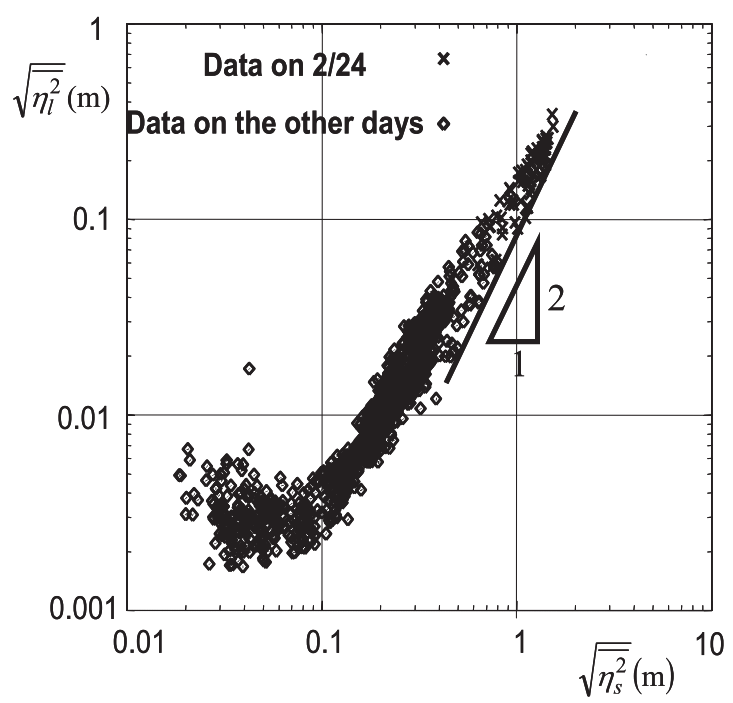

図-4 各時系列における $\sqrt{\eta_{s}^{2}}$ と $\sqrt{\eta_{l}^{2}}$ の相関図 


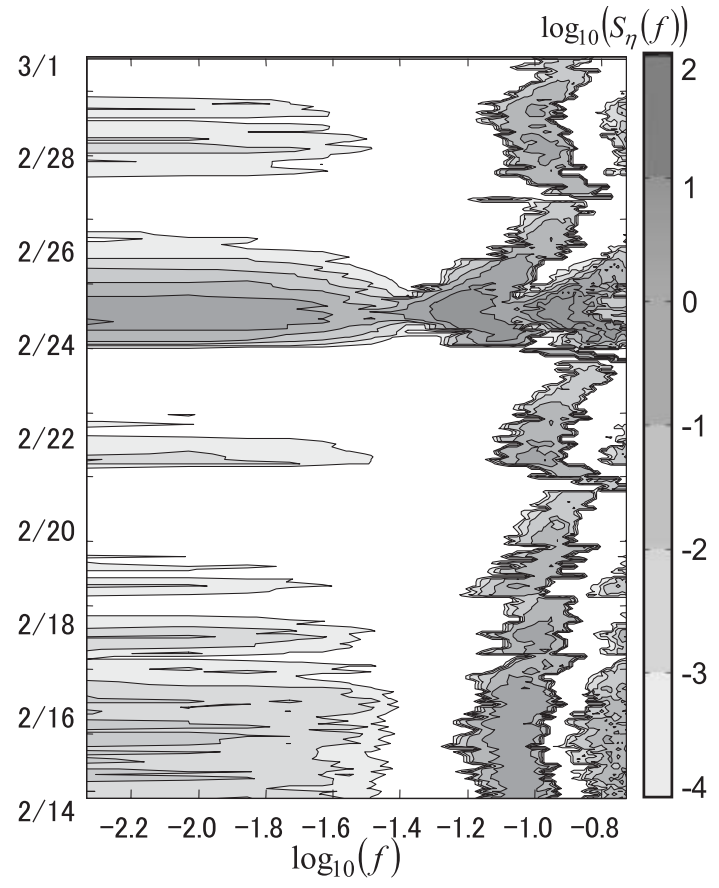

図-5 二次干渉理論によるスペクトル密度の計算值

大波浪来襲時の 2 月 24 日付近において長周期波の発達が よく再現されていることがわかる。したがって本研究で 対象としたうねり性波浪については，長周期変動成分の 多くは線形波内で周波数のわずかに異なる成分波同士が 互いに非線形干渉を起こすことによって生じたものであ ると考えられる。な扔，非線形干渉計算ではピーク周辺 のスペクトル強度が大きい，すなわち周波数のよく揃つ た波に扔いて非線形成分が大きくなる。このことに注目 すると，風波発生場所から長距離を伝播することで周波 数がよく揃った状態となるうねり性波浪は長周期成分, 倍周波数成分が発達しやすい傾向にあるということが分 かる。これらの非線形成分が発達した波浪は水位変動值 のピークが尖鋭となることでさらに越波量が多くなり， 沿岸区域に被害をもたらす結果となりやすい.

\section{3. 田中観測所データを用いた下新川海岸におけ る沿岸流の分析}

うねり性巨大波浪が来襲した時間帯の前後を含んだ 2 月 23 日 0 時 10 分から 2 月 25 日 23 時 50 分までにおいて風 速 $(\mathrm{m} / \mathrm{s})$ および底層・中層の流速 $(\mathrm{cm} / \mathrm{s})$ と、風向きお よび沿岸流の流向（度，北を $0^{\circ}$ として時計回りの角度） の 20 分ごとの平均值の時系列変化分布を図化した（図-6, 図-7). 図-6より，24日の 8 時ごろから底層，中層ともに 流速が急激に増加し， $100 \mathrm{~cm} / \mathrm{s}$ を超える大きな流速が観 測されていたことがわかる。しかしその際風速は急激な 変化をせず，むしろ穏やかな減少傾向を示している。ま
た，流向については図-7によると図-6と同様の時刻に底 層，中層双方において東向きから西向きへと急激に変化 していることが分かる．な拉，その際風向については西 から東へ吹く向きで概ね変化はなかったことが確認でき る。すなわち 2 月 24 日 8 時以前は風向と沿岸流の流向は 同一で，それ以後は互いに逆となった状態が36時間程度 継続していたことが分かった。この時間帯はうねり性巨 大波浪が下新川海岸に来襲した時間带と合致している.

このようにうねり性巨大波浪が来襲した際に下新川海 岸の沿岸流速は水深 $13 \mathrm{~m}$ 程度の沖合においても急激に増 加し, 加えて流向も大きく変化したがその時の風速, 風 向に大きな変動は見られなかった。よって波浪来襲時に 発生した強い沿岸流は風に起因するものであるとは考え づらく, 先述したうねり性波浪の特性と下新川海岸沿岸 の特徴的な海底地形が影響しあって生じたものであるこ とが推察される。

\section{4. 下新川海岸地形における数値モデルを用いた解析}

前述の田中観測所付近で観測された強い沿岸流と，う ねり性巨大波浪の被害区域周辺での波浪変形を数值モデ ルによる波浪変形計算で再現することを試みた。

海底地形デー夕は2005年10月から 12 月にかけてナロ

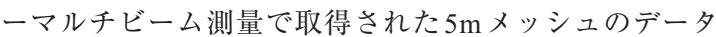

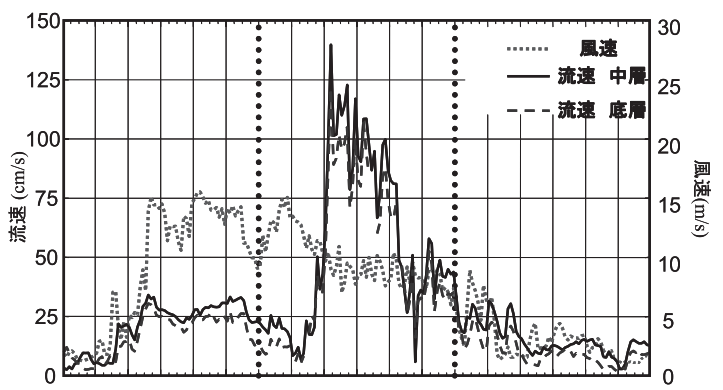



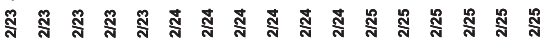

図-6 田中観測所の風速及び流速の時系列変動

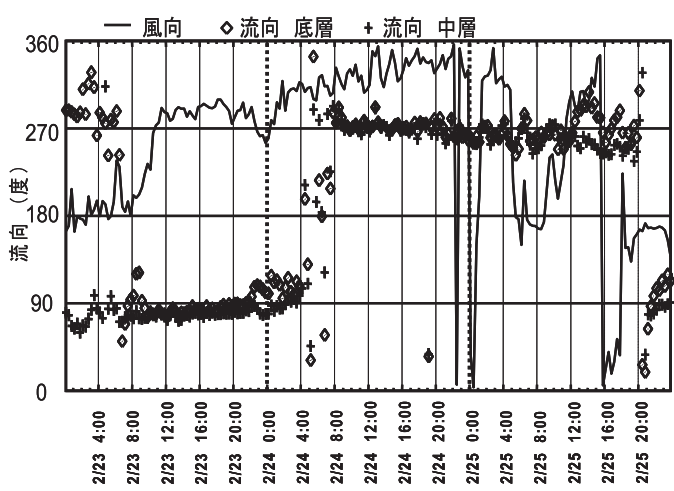

図-7 田中観測所の風向及び流向の時系列変動 
を用いた。波浪に関する詳細なデータの得られた田中観 測所周辺区域に加えて被害が集中した黒部川右岸の芦崎 地区や左岸側の生地地先を対象として計算を実施した。 数值計算はNwogu（1993）によるブシネスク方程式を用 い, $60 \mathrm{~m}$ 以浅の水深を再現した地形に対して, 波高 $H=$ $8.0 \mathrm{~m}$ ，周期 $T=14 \mathrm{~s}$ の波を北から入射させた。砕波の発生 については、ある地点において水深 $h$ に対して $Z_{\alpha} / h=0.531$ となるような深度 $Z_{\alpha}$ での流速 $U_{\alpha}$ を用い, 同地点での波 速 $c$ に対して $U_{\alpha} / c>0.35$ となることを条件とした. 砕波 後の波浪変形にはKennedyら（2000）のモデルを用い，砕 波によるエネルギー減衰は渦粘性係数により評価した。 渦粘性係数は、乱流エネルギーと乱れスケールを介して 評価した。その結果得られた波高分布を色の濃淡, 沿岸 流速と方向を矢印とし, 海底地形等高線図とともに表示 した。なお，図の縦軸、横軸はそれぞれ日本測地系（第 七系) のX座標 $(\mathrm{m})$, Y座標 $(\mathrm{m})$ である.

図-8に示す田中観測所周辺での地形・沿岸流・波高分 布を見ると, 四中に丸印で示した田中観測所観測地点に おける沿岸流について, 前章で述べたような強い西向き の流れは再現されなかったが, 図の北東部・南西部では 水深 $13 \mathrm{~m}$ 付近の沖合で流速 $1 \mathrm{~m} / \mathrm{s}$ を超える西向きの強い沿 岸流が生じていることが確認された，同様に生地地区・ 芦崎地区における計算結果をそれぞれ図-9, 図-10に示し た，生地地区については，図-9を見ると北東部から中央 部にかけて流速 $1 \mathrm{~m} / \mathrm{s}$ 前後の強い沿岸流がほぼ海岸線に沿 って発生しており, 海底地形の急変する中央部において 波高が増大していることが分かる。これは海底地形が複 雑に変化していることにより波浪が屈折し, 浅水域で波 が集中するとともに，屈折した波が沿岸流と干渉して波 高を増大させたことに起因しているものと考えられる.

図-10に示した芦崎地区においても同様に概ね西向き に強い沿岸流が生じているが, 所々に沖側である北西へ 向かう流れが見られる.さらに海底の尾根となっている ような地形の急変部では波高が特に増大している.また, 両地区ともに実際の被害の集中個所で波高が大きくなっ ていることが確認され，そこでは総じて強い沿岸流場が 発生している. 特に芦崎地区に打いては, 被害区域周辺 の沖向き沿岸流が他の区域に比べて発達していることが 確認できる.

本研究の事例では, 生地, 芦崎両地区において沿岸流 が沖へ向かう離岸流が発生している筒所があり, その地 点で屈折の影響で波向が変化した波浪と互いに逆向きと なり, 波高が増大していたと考えられる。流速 $1 \mathrm{~m} / \mathrm{s}$ 前後 の強い沿岸流場が水深 $h=10 \mathrm{~m}$ 程度の浅水域で発達してい たことを考慮すると, 被害区域周辺では沿岸流との干渉 作用による波浪振幅の増大が無視できない状態であった と考えられる.



図-8 田中観測所（図中○印）周辺における波浪算定結果



図-9 生地地区周辺における波浪算定結果 


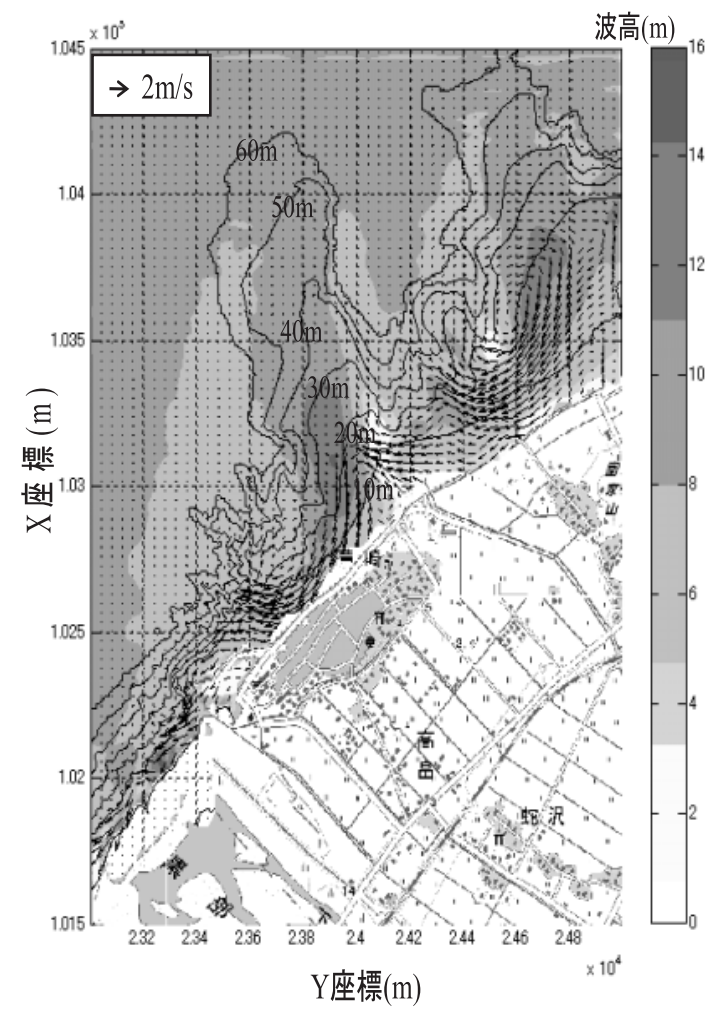

図-10＼cjkstart芦崎地区周辺における波浪算定結果

以上のモデルによる波浪計算から，下新川海岸地域で 発生した巨大波浪については, 海岸付近の海底地形が急 勾配であることによるエネルギー減衰の不足や，複雑な 海底地形において屈折が生じて波が集中することによる 波高増大といった地形上の要因が確認された.ささに被 害区域では強い沿岸流場が発達しており, そのなかで沖 側へ向かう沿岸流が波浪と逆向きに干渉することも要因 として考えられることが分かった。 下新川海岸地域のよ うに複雑な地形によって波浪が屈折を繰り返し，様々な 方向に進行する状況では，このような波浪と沿岸流の相 互干渉が波高増大について十分に考慮すべき要素となる と言える.

\section{5. まとめ}

2008年2月 24 日に下新川海岸を襲ったうねり性巨大波 浪について, 詳細な観測データからスペクトル・沿岸流 にまつわる特性を分析した。その結果，うねり性波浪で はスペクトルピーク周波数周辺の波が互いに非線形干涉 することで長周期変動成分や倍周波数成分が発達し, 越 波の増大をもたらすことが分かった。また，被害発生時 周辺で水深に対して大きな流速をもった沿岸流が生じて いたことが明らかとなり，これは数值モデルを用いた波 浪計算においても再現された。同様の計算を被害集中地 域についても実施した結果, 被害区域での波高の増大が 確認され，それ以外にも局地的な高波浪の分布が得られ た.その要因として, 波浪の屈折, 集中を誘発する複雑 な地形以外に，比較的強い沿岸流場において沖向きの沿 岸流と波浪が互いに逆向きに干涉し, 波高が増大すると いうことも十分に考えられることが明らかとなった。

謝辞：本研究は鉄道建設・運輸施設整備支援機構の「運 輸分野における基礎的研究推進制度」により実施したも のである.うねり性波浪の特性および被害発生時期の海 浜流場の分析にあたり, 国土交通省黒部河川事務所から 田中観測所の貴重なデータやナローマルチビームによる 詳細な海底地形データをいただいた。ここに深甚なる謝 意を表する。

\section{参 考 文 献}

浜田徳一（1964）：表面波の2次干渉，第12回海岸工学講演会 講演集, pp.12-18.

Kennedy, A. B., Q. Chen, J. T. Kirby and R. A. Dalrymple(2000) : Boussinesq modeling of wave transformation, breaking and run-up, I : 1D, Journal of Waterways, Port, Coastal and Ocean Engineering, ASCE, Vol.126, WW1, pp.39-47.

Nwogu, O.J.(1993) : Alternative form of Boussinesq equations for nearshore wave propagation, Journal of Waterways, Port, Coastal and Ocean Engineering, ASCE, Vol.119, WW6, pp.618-638. 